\title{
Analysis of tert-Butanol, Methyl tert-Butyl Ether, Benzene, Toluene, Ethylbenzene and Xylene in Ground Water by Headspace Gas Chromatography-Mass Spectrometry
}

\author{
Ho-Sang Shin ${ }^{\times}$and Tae-Seung Kim
}

\author{
Department of Enwironmenal Education, Konglu National Lhiversitw, Kongh 31-701, Korea. ${ }^{*}$-mail: hshinalkonghuac.kr \\ Drinking Water Research Division. National Institute of Envirommental Research. Korea \\ Recened October 22, 2009, Accepted November 2, 2009
}

\begin{abstract}
Methyl tert-butyl ether (MTBE) is added to gasoline to enhance the octane number of gasoline, tert-butyl alcohol (TBA) is major degradation intemediate of MTBE in environment, and benzene, toluene, ethyl benzene and xylene (BTEX) are also major constituents of gasoline. In this study, a simplified headspace analy sis method was adapted for simultaneous deternination of MTBE, TBA and BTEX in ground water samples. The sample $5.0 \mathrm{~mL}$ and $2 \mathrm{~g} \mathrm{NaCl}$ were placed in a $10 \mathrm{~mL}$ vial and the solution was spiked with fluorobenzene as an intemal standard and sealed with a cap. The vial was placed in a heating block at $85^{\circ} \mathrm{C}$ for $30 \mathrm{~min}$. The detection limits of the assay were $0.01 \mu \mathrm{g} / \mathrm{L}$ for MTBE and BTEX, and $0.02 \mu \mathrm{g} / \mathrm{L}$ for TBA. The method was used to analyze 110 ground water samples from various regions in Korea, and to survey the their background concentration in ground water in Korea. The samples revealed MTBE concentrations in the range of $0.01-0.45 \mu \mathrm{g} / \mathrm{L}$ (detection frequency of $57.3 \%$ ). TBA concentrations in the range of $0.02-0.08 \mu \mathrm{g} / \mathrm{L}$ (detection frequency of $5.5 \%$ ), and total BTEX concentrations in the range of $0.01-2.09$ tug/L (detection frequency of $87.3 \%$ ). The developed method may be used when simultaneously determining the anount of MTBE, TBA and BTEX in water.
\end{abstract}

Key Words: MTBE. TBA. BTEX. Headspace GC-MS. Ground water

\section{Introduction}

Methyl tert-butyl ether (MTBE) is used worldwide as an antiknock additive that can increase the octane mumber. MTBE has gained increasing attention over the past decade because of its widespread contamination in the environment as a result of the leaking of underground fuel storage tanks. Tert-butyl alcohol (TBA) is a degradation intermediate of MTBE and is also applied as a fitel additive. ${ }^{1}$ MTBE is considered to be a possible hllman carcinogen and TBA is considered to be a probable human carcinogen by the US Environmental Protection Agency ${ }^{27}$ Benzene, toluene, ethyl benzene and sylene (BTEX) are also major constituents of gasoline.

Exhaust emissions from vehicles. as well as evaporative losses from gasoline stations and velicles. are major sources of MTBE and BTEX that are released in the atmosphere. Because of their ability to persist in the atmosphere from days to weeks. and because they will in part. dissolve into water. MTBE and BTEX are expected to be present in precipitation in direct proportion to their concentration in air. Hence. in the atmosphere MTBE and BTEX provide a non-point. low concentration source to the hydrologic cycle as a result of the dispersive effect of weather patterns and the occurrence of precipitation. ${ }^{4}$ The volatilization of MTBE and BTEX occurs slowly from ponds and lakes, as well as from slow-moving and deep streams and rivers. Volatilization can also be rapid in shallow and fast-moving streams and rivers. However. MTBE is much less biodegradable than BTEX and therefore. will persist longer in ground water. MTBE also only weakly adsorbs to soil and aquifer material. Consequently. the dissolved MTBE moves with the ground water flow and can migrate fiuther from a point source of contamination. A number of countries have become concerned about the background concentration of MTBE in groundwater, and have collected background data for the purpose . $^{5-3}$ From this point of view. a study was developed in order to deternine the amount of MTBE distribution in the groundwater of Korea. For the purpose, the method must be very sensitive and accurate.

There are many different techniques available for measuring MTBE, TBA and BTEX, as well as its extraction from water. Gas chromatographic (GC) methods have used to analy ze of MTBE, TBA and BTEX. Mass spectrometry (MS) has the potential to become a standard analytical tool for detecting these compounds. Sensitive analysis is also usually accomplished by gas chromatography-mass spectrometry (GC-MS). Although most procedures utilize GC-MS to quantify the analytes. these procedures differ substantially with respect to sample extraction and concentration.

MTBE in ground water is frequently prepared by using the standard U.S.EPA method that was originally developed for the analy sis of BTEX ${ }^{8}$ This method uses purge and trap (P\&T) with gas chromatography mass spectrometric detection (GC-MS). Purge and trap (P\&T) is by far the nost frequently applied technique for the extraction and concentration of MTBE and BTEX in water. ${ }^{9.11}$ However, this method can produce false quantification of MTBE and TBA in hydrocarbon mixtures due to the contamination in the P\&T system with target or nontarget conpounds having sinular retention times in the presence of ligh concentrations of hydrocarbons. Recently, a specific and highly sensitive method for MTBE analy sis has been developed that relies on headspace solid phase microextraction (SPME). ${ }^{11-19}$ The methods have many advantages in it being convenient and having rapid and automatic extraction. but its low recovery due to the volatility and long loading time of the SPME fibre.

MTBE. TBA and BTEX are antiknock additive, major meta- 
bolite. constituents of gasoline, respectively. Therefore, the co-contamination of MTBE. TBA and BTEX is commonplace. The used procedures to this day include the analytical method of one or two among the three co-contaminants. Surprisingly, no conventional headspace GC-MS procedure has been used for the simultaneous detection of a trace of MTBE, TBA and BTEX in water.

This paper describes a conventional head space procedure that tries to trace MTBE. TBA and BTEX in water combined with analy'sis of gas chromatography-mass spectrometry-selected ion monitoring (GC-MS-SIM). A simple and reproducible procedure for the simultaneous analysis of MTBE. TBA and BTEX was the target of this study. The method was applied in order to determine the amount of MTBE. TBA and BTEX in the ground water in Korea.

\section{Experimental}

Chemicals and reagents. MTBE. TBA benzene, toluene. ethyl benzene, sylene and fluorobenzene were purchased from Aldrich (USA). An analy tical grade of sodium hydrogensulfate monohydrate sodium chloride phosphoric acid. acetone and methanol were from J. T. Baker (USA). The water was purified by using milli-Q equipment (Millipore Corp.. Milford. MA. USA).

Spiking. Spiked samples were prepared by milli-Q water ( $100 \mathrm{~mL}$ ) that was spiked with $10-100 \mu \mathrm{L}$ of standard solutions at a concentration of $0.05-5.0 \mathrm{mg} / \mathrm{L}$ and with $50 \mu \mathrm{L}$ of the solution containing internal standards at a concentration of $2.0 \mathrm{mg} / \mathrm{L}$.

Extraction procedure. $5.0 \mathrm{~mL}$ of the water sample were placed in $10 \mathrm{~mL}$ headspace vial. saturated with $\mathrm{NaCl}$ and the solution was spiked with fluorobenzene as an intemal standard and sealed with cap. The vial was placed in a heating block for 40 min at $80^{\circ} \mathrm{C}$

Gas chromatography-mass spectrometry. An Agilent 6890/ $5973 \mathrm{~N}$ instnument and a Combipal Autosampler (Agilent. USA), which could do automated HS (SPME) injections, were used. The ion source was operated in the electron ionization mode (EI: 70 eV. $230^{\circ} \mathrm{C}$ ). Full-scan mass spectra $(m / z+0-800$ ) were recorded in order to identify the analy tes at a high concentration. The confirmation of trace chemicals was completed by two MS characteristic ions, the ratio of two MS characteristic ions and GC-retention times matches to the known standard compounds. The ions selected in this study and the operating parameters of GC-MS are shown in Table 1.

Calibration and quantification. Calibration curves for MTBE. TBA and BTEX were established by extraction after adding $0.2,0.5,1.0,2.5,5.0$ and $10.0 \mathrm{ng}$ of standards and $5.0 \mathrm{ng}$ of internal standard (f-benzene) in $5.0 \mathrm{~mL}$ of milli-Q water. The ratio of the peak area of the standard to that of the internal standard was used in the quantification of the compound.

Ground WaterSampling, Ground water samples were collected from 55 developed wells in order to determine the amount of MTBE. TBA and BTEX in the ground water. Sampling sites were selected to distribute uniformly in all cities and Do (not including Jejudo) of Korea as shown in Table 2. Sampling sites are located in rural area and there is no gasoline station within $1 \mathrm{~km}$ around them.
Table 1. GC-MS conditions used for analyzing MTBE, TBA and BTEX

\begin{tabular}{lccc}
\hline Parameters & \multicolumn{3}{c}{ Conditions } \\
\hline Columur & $30 \mathrm{~m} \times 0.25 \mathrm{~mm}$ id. $\times 0.25 \mu \mathrm{m}$ film Innowax \\
Carrier gas & He at $0.9 \mathrm{~mL} \mathrm{~min}^{-1}$ \\
Oven temperature & $35^{\circ} \mathrm{C}(1 \mathrm{~min})$ to $70^{\circ} \mathrm{C}(3 \mathrm{~min})$ at $5^{\circ} \mathrm{C} \mathrm{min}^{-1}$ \\
Inlet mode & Pulse splitless \\
Injector temperature & $250^{\circ} \mathrm{C}$ \\
Transfer temperature & $280^{\circ} \mathrm{C}$ & & \\
& Group & Time $($ min $)$ & $(\mathrm{m} / 2)$ \\
\cline { 2 - 4 } & 1 & 1.0 & 57,59 \\
Selected ion group & 2 & 1.4 & $41,57,73$ \\
& 3 & 2.1 & 78,96 \\
& 4 & 3.5 & 91,92 \\
& 5 & 6.5 & 91,106 \\
\hline
\end{tabular}

Table 2. City and Do distribution of sampling sites in this study

\begin{tabular}{|c|c|c|c|c|c|c|c|}
\hline \multicolumn{2}{|c|}{ Sampling Gyong- } & \multirow{2}{*}{$\begin{array}{c}\text { Gang- } \\
\text { won }\end{array}$} & \multirow{2}{*}{\multicolumn{2}{|c|}{$\begin{array}{l}\text { Chung- Chung- } \\
\text { nam buk }\end{array}$}} & \multirow{2}{*}{ Deajon } & \multicolumn{2}{|c|}{ Gyong-Gyong- } \\
\hline Area & $\mathrm{gi}$ & & & & & buk & nam \\
\hline Site $\mathrm{Nr}$ & 9 & 6 & 4 & 9 & l & 3 & 6 \\
\hline $\begin{array}{c}\text { Sampling } \\
\text { Area }\end{array}$ & Degu & Ulsan & Busan & Tunbuk & Junnam & $\begin{array}{c}\text { Gwang- } \\
\text { ju }\end{array}$ & Total \\
\hline Site $\mathrm{Nr}$ & 1 & 3 & 2 & 8 & 2 & 1 & 55 \\
\hline
\end{tabular}

\section{Results and Discussion}

Optimization of headspace conditions. Method optimization was principally performed in the selection of the best headspace temperature and the best heating time for the simultaneous analysis of MTBE. TBA and BTEX in water samples.

Prelinuinary testing at $50,60.70,80.85$ and $90^{\circ} \mathrm{C}$ was performed by analyzing three spiked water samples. The peak area of each spiked compound was used for comparison. In all cases, better efficiencies were obtained at a ligh temperature $\left(85^{\circ} \mathrm{C}\right)$ as shown in Fig. 1. For TBA. the small peak was detected below $70^{\circ} \mathrm{C}$, due to its ligh solubility in water and low the Henry's law constant.

The optinum heating time of the target compounds was performed by analyzing the three spiked water samples. The target conpounds were analyzed at heating times of $10.20,30,40.50$ and $60 \mathrm{~min}$ at $85^{\circ} \mathrm{C}$. The maximum peak areas were obtained in 30 min of heating time (Fig. 2).

Verification of method perfomance. For the GC separation of BTEX. MTBE and TBA. the use of the semi polar stationary phase was found to be efficient. Chromatograms are shown in Fig. 3. As can be seen from the figures, the peaks of BTEX. MTBE and TBA. as well as the internal standard, are symmetrical. This indicates that the separation of the analytes from the background compounds in the water samples was good. The retention times of TBA. MTBE. benzene. F-benzene (ISTD), toluene. ethylbenzene, $m, p$-xylene, and $o$-xylene were 2.15 . $2.45,2.87,3.02 .4 .86 .7 .58,7.79$ and 8.38 min. respectively There were no extraneous peaks obsened in the chromatogram 


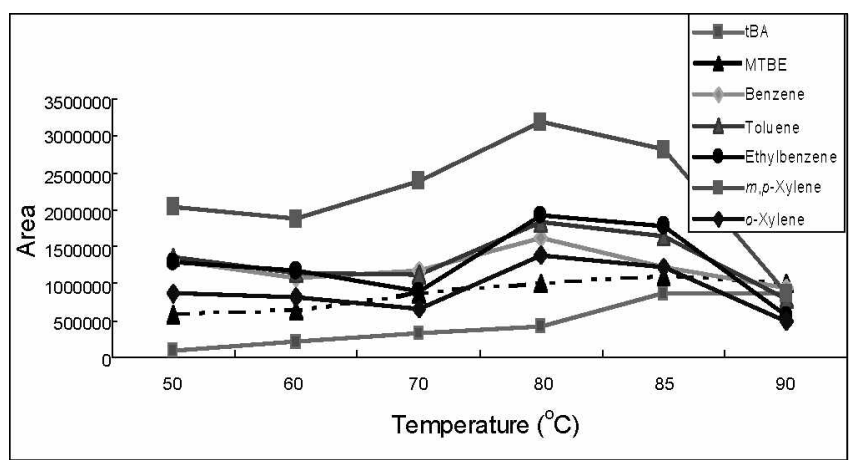

Figure 1. Peak area changes of the target compounds according to the change of heating temperature.

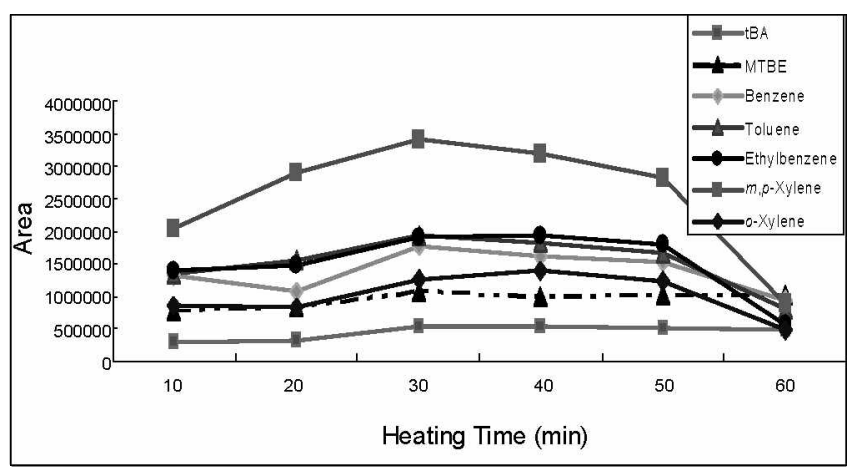

Figure 2. Peak area change of the target componnds according to the change of heating times.

of blank water in the time range between 2.0 and $9.0 \mathrm{~min}$.

Calibration curves of MTBE. TBA and BTEX were constructed by extracting the spiked water samples. A typical standard curve was examined by computing a regression line of peak area ratios for BTEX. MTBE and TBA to the internal standard on concentration by using a least-squares fit. The analysis demonstrated a linear relationship with correlation coefficients being greater than $r^{2}=0.997$ (Table 3)

Detection limits were $0.01 \mu \mathrm{g} / \mathrm{L}$ for BTEX and MTBE. and $0.02 \mu \mathrm{g} / \mathrm{L}$ for TBA based on an assayed water that was spiked with the concentration of $0.01 \mu \mathrm{g} / \mathrm{L}$ (Table 3). Detection limits were defined by 3.14 times of coefficients of variation for replicate determinations $(n=7)$ of the sample.

The range and standard deviation values for the precision and accuracy are given in Table t. For five independent determinations at 1.0 and $0.1 \mu \mathrm{g} / \mathrm{L}$. the coefficient of variation was

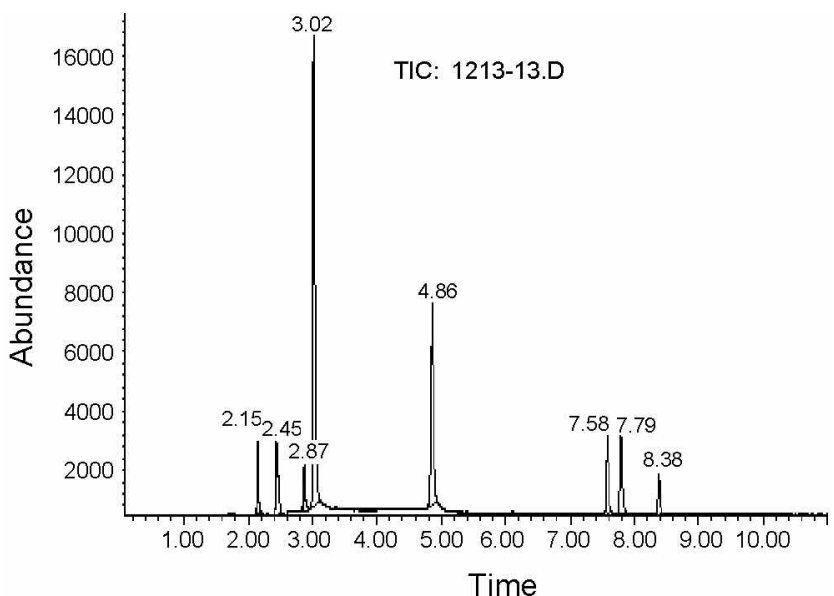

Figure 3. Chromatogram of TBA, MTBE and BTEX spiked in mineral water. 2.15: TBA, 2.45: MTBE, 2.87:Benzene, 3.02: ISTD(FB) 4.86: Toluene, 7.58: Ethylbenzene, 7.79: $m, p$-Xylene, 8.38: $o$-Xylene (each $0.05 \mu \mathrm{g} / \mathrm{L}$ in mineral water).

less than $16 \%$.

Gound water analysis. Ground water samples from 55 developed wells were analyzed for the presence of MTBE. TBA and BTEX by using the method developed for this study. This study describes the results of a statistical analy sis on MTBE. TBA and BTEX back ground concentration distributions in the ground water in Korea. In the $\mathrm{I}^{\text {st }}$ survey. the samples that were taken at 55 sites revealed MTBE concentrations in the range of $0.01-0.19 \mu \mathrm{g} / \mathrm{L}$ (detection frequency of $49.1 \%$ ), TBA concentrations in the range of $0.0 \mathrm{l}-0.05 \mu \mathrm{g} / \mathrm{L}$ (detection frequency of $5.5 \%$ and total BTEX concentrations in the range of $0.0 \mathrm{~L}-1.06 \mu \mathrm{g} / \mathrm{L}$ (detection frequency of $74.6 \%$ ). The median and mean concentrations found at the contaminated sites were 0.04 and $0.01 \mu \mathrm{g} / \mathrm{L}$ for MTBE. 0.01 and $0.00 \mu \mathrm{g} / \mathrm{L}$ for TBA. and 0.11 and $0.03 \mu \mathrm{g} / \mathrm{L}$ for total BTEX. respectively.

In the 2nd survey, the samples that were taken at the 55 sites revealed MTBE concentrations in the range of $0.01-0.45 \mu \mathrm{g} / \mathrm{L}$ (detection frequency of $71.4 \%$ ). TBA concentrations in the range of $0.0 \mathrm{l}-0.08 \mu \mathrm{g} / \mathrm{L}$ (detection frequency of $5.5 \%$ ), and BTEX concentrations in the range of $0.01-2.09 \mu \mathrm{g} / \mathrm{L}$ (detection frequency of $100 \%$ ). The median and mean concentrations found at the contaminated sites were 0.03 and $0.01 \mu \mathrm{g} / \mathrm{L}$ for MTBE, 0.01 and $0.00 \mu \mathrm{g} / \mathrm{L}$ for TBA. and 0.14 and $0.05 \mu \mathrm{g} / \mathrm{L}$ for BTEX, respectively.

When the surveys were combined, the 110 samples revealed MTBE concentrations in the range of $0.0 \mathrm{l}-0.45 \mu \mathrm{g} / \mathrm{L}$ (detection

Table 3. Calibration curves and method detection limits of MTBE TBA and BTEX in ground water

\begin{tabular}{lcccc}
\hline Compound & Linear regression & Concentration range $(\mu \mathrm{g} / \mathrm{L})$ & Correlation coefficient & MDL $(\mu \mathrm{g} / \mathrm{L})$ \\
\hline MTBE & $\mathrm{Y}=0.0712 \mathrm{x}-0.0014$ & $0.01-10$ & 0.9993 & 0.01 \\
TBA & $\mathrm{Y}=0.0689 \mathrm{x}+0.0011$ & $0.02-10$ & 0.9989 & 0.02 \\
Benzene & $\mathrm{Y}=0.0873 \mathrm{x}-0.0073$ & $0.01-10$ & 0.9989 & 0.01 \\
Toluene & $\mathrm{Y}=0.0998 \mathrm{x}+0.0101$ & $0.01-10$ & 0.9989 & 0.01 \\
Ethylbenzene & $\mathrm{Y}=0.1166 \mathrm{x}-0.0113$ & $0.01-10$ & 0.9983 & 0.01 \\
$m$-Xylene & $\mathrm{Y}=0.0871 \mathrm{x}-0.0080$ & $0.01-50$ & 0.9986 & 0.01 \\
$p$-Xylente & $\mathrm{Y}=0.0833 \mathrm{x}-0.0073$ & $0.01-10$ & 0.9986 & 0.01 \\
$o$-Xylente & $\mathrm{Y}=0.0680 \mathrm{x}-0.0036$ & $0.01-10$ & 0.9978 & 0.01 \\
\hline
\end{tabular}


Table 4. Intra laboratory precision and accuracy results for the analy sis of MTBE, TBA and BTEX in water

\begin{tabular}{|c|c|c|c|c|c|c|c|c|}
\hline \multirow{3}{*}{$\begin{array}{l}\text { Compound } \\
\text { MTBE }\end{array}$} & \multirow{2}{*}{$\frac{\text { Spiked }(\mu \mathrm{g} / \mathrm{L})}{1.00}$} & \multicolumn{6}{|c|}{ Measured Conc. $(\mu \mathrm{g} / \mathrm{L})$} & \multirow{2}{*}{$\frac{\text { Mean } \pm \text { SD (RSD \%) }}{0.94 \pm 0.0+(+0+4)}$} \\
\hline & & 0.96 & 0.97 & 0.87 & 0.93 & 0.99 & 0.94 & \\
\hline & 0.10 & 0.09 & 0.08 & 0.07 & 0.09 & 009 & 0.10 & $0.09 \pm 0.01(10.9)$ \\
\hline \multirow[t]{2}{*}{ TBA } & 1.00 & 0.78 & 0.88 & 0.90 & 0.99 & 1.01 & 0.91 & $0.91=0.08(8.29)$ \\
\hline & 0.10 & 0.09 & 0.09 & 0.08 & 0.11 & 0.12 & 0.08 & $0.10 \pm 0.02(15.8)$ \\
\hline \multirow[t]{2}{*}{ Benzene } & 1.00 & 0.94 & 0.97 & 0.93 & 0.92 & 0.95 & 0.99 & $0.95 \pm 0.02(2.5)$ \\
\hline & 0.10 & 0.09 & 0.12 & 0.09 & 0.09 & 0.09 & 0.08 & $0.09 \pm 0.01(13.4)$ \\
\hline \multirow[t]{2}{*}{ Toluene } & 1.00 & 0.96 & 1.21 & 0.96 & 1.12 & 0.97 & 1.00 & $1.04 \pm 0.10(9.20)$ \\
\hline & 0.10 & 0.09 & $0.1 \hat{3}$ & 0.12 & 0.13 & 0.11 & 0.11 & $0.12 \pm 0.01(12.0)$ \\
\hline \multirow[t]{2}{*}{ Ethylbenzene } & 1.00 & 0.94 & 1.00 & 0.95 & 1.28 & 1.14 & 1.01 & $1.05 \pm 0.12(11.4)$ \\
\hline & 0.10 & 009 & 008 & 0.09 & 0.11 & 0.12 & 0.08 & $0.10 \pm 0.02(15.8)$ \\
\hline \multirow[t]{2}{*}{$m, p$-Xylene } & 1.00 & 0.92 & 0.99 & 0.94 & 0.99 & 1.14 & 0.99 & $1.00=0.07(7.08)$ \\
\hline & 0.10 & 0.09 & 0.08 & 0.08 & 0.07 & 009 & 0.10 & $0.09 \pm 0.10(11.3)$ \\
\hline \multirow[t]{2}{*}{$o$-Xylene } & 1.00 & 0.96 & 1.00 & 0.94 & 0.98 & 1.01 & 1.22 & $1.02 \pm 0.09(9.15)$ \\
\hline & 0.10 & 0.08 & 0.09 & 0.08 & 0.09 & 0.12 & 0.11 & $0.10 \pm 0.02(15.8)$ \\
\hline
\end{tabular}

frequency of $57.3 \%$ ). TBA concentrations in the range of $0.0 \mathrm{l}$ $0.08 \mu \mathrm{g} / \mathrm{L}$ (detection frequency of $5.5 \%$ ), and BTEX concentrations in the range of $0.01-2.09 \mu \mathrm{g} / \mathrm{L}$ (detection frequency of $87.3 \%$ ). The median and mean concentrations found at the contaminated sites were 0.04 and $0.01 \mu \mathrm{g} / \mathrm{L}$ for MTBE. 0.01 and $0.00 \mu \mathrm{g} / \mathrm{L}$ for TBA and 0.13 and $0.04 \mu \mathrm{g} / \mathrm{L}$ for total BTEX. respectively.

These results were lower than the results of studies conducted in various European countries, where the median amount of MTBE detected was $0.06 \mu \mathrm{g} / \mathrm{L}$ at 60 of $1+1$ investigated sites in Germany $0.04 \mu \mathrm{g} / \mathrm{L}$ at 200 of 200 investigated sites in Switzerland at concentrations above $0.01 \mu \mathrm{g} / \mathrm{L}$. The results of this study. were also lower than the results of a stidy conducted in the USA. where the median amount of MTBE found was $0.5 \mu \mathrm{g} / \mathrm{L}$ at 422 with a concentration above $0.0 \mathrm{l} \mu \mathrm{g} / \mathrm{L}$. These findings support the assumption that there is still decreasing MTBE pollution in the groundwater, perhaps due to the monitoring for gasolinecontaminated sites that has been carried out in Korea since 1997.

\section{Conclusions}

In this paper. the analy tical parameters critical to the MTBE. TBA and BTEX headspace extraction method as well as the GC-MS characteristics were examined. It was discovered that the HS heating temperature of $85^{\circ} \mathrm{C}$. and the heating time of 30 min was found to be the most effective. Using the innowax column showed that the peaks of BTEX. MTBE and TBA have good chromatographic properties and a show sensitive response for the EI-MS (SIM). The method detection limit of target compounds was $0.01 \cdot 0.02 \mu \mathrm{g} / \mathrm{L}$. The method was used to analyze 110 ground water samples from various regions in Korea. The samples taken at the contaminated sites revealed MTBE concentrations in the range of $0.01-0.45 \mu \mathrm{g} / \mathrm{L}$ (detection frequency of $57.3 \%$ ). TBA concentrations in the range of $0.0 \mathrm{~L}-0.08 \mu \mathrm{g} / \mathrm{L}$ (detection frequency of $5.5 \%$ ) and total BTEX concentrations in the range of $0.01-2.09 \mu \mathrm{g} / \mathrm{L}$ (detection frequency of $87.3 \%$ ).
The developed method may be valuable simultaneously deternining the anount of MTBE. TBA and BTEX in water.

\section{References}

1. Interagency Assessment of Oxygenated Fuels, 1997, National Science and Technology Council, Committee on Environment and Natural Resources

2. USEPA (1998) EPA/600/R-98/048, Oxygenates in water: critical infonmation and research needs.

3. USEPA (1999) EPA 420-R-99-021, Achieving clean air and clean water. The report of the blue ribbon panel on oxygenates in gasoline.

4. National Science and Technology Council, Committee on Environment and Natural Resources, USA, 1997, Interagency Assessment of Oxygenated Fuels.

5. Kolb, A.; Puttmann, W. Wat. Res. 2006, f0(19), 3551.

6. Schmidt, T. C.; Haderlein, S. B.; Ptister, R.; Forster, R. Wat. Res. $2004,38,1520$

7. Schmidt, C. T.; Morgenroth, E.; Schimer, M:; Effenberger, M: Haderlein, S. B. Oxgenates in Gasoline: Envinommental Aspects: American Chemical Society: Washington, DC., USA, $2002 ;$ p. 58.

8. USEPA (2009) METHODEPA 524.3, Measurement of purgeable organic compounds in water by capillary column gas chromatography/mass spectrometry

9. Bianchi, A. P.; Vaney, M. S. J. High Resol. Chromatogr. 1989. 12. 184

10. Halden, R. U.; Happel, A. M.; Schoen, S. R. Emiron. Sci. Tecinol. $2001,35,1469$

11. Wei, C., Tiemin, L.; Guibin, I. Int. J. Enwon. Anal Chem 2003. $83(4), 285$

12. Achten, C.; Kolb, A. Fresenius J. Anal Chem 2001, 371(4), 519.

13. Stringfellow, W. T.; Oh, K. C. Ground Water Hontit. Rem. 2005, $25(2), 52$

14. Zuccarello, I. L.; Ganske, J. A.: Green, D. B. Chemosphere 2003. $51(8), 805$

15. A. Erdem-Senatalar, A.: Bergendahl, J. A.; Thompson, R. W. Chenosphere 2004, 57(6), 523

16. Atienza, J-; Aragón, P. Chit Rew Anal. Chent 2005, 35(4), 317.

17. Cassada, D. A.; Zhang, Y.; Snow, D. D. Anal Chem 2000, 72(19), 4654 .

18. Dewsbury, P.: Thornton, S. F.: Lemer, D. N. Enwinon Sci. Techmol. $2003,37(7), 1392$.

19. Schmidt. T. C. Trends in Anal. Chem. 2003, 22(10), 776 . 